\title{
New data on the myriapod fauna (Myriapoda: Chilopoda, Diplopoda) of the Republic of Khakassia, central Siberia, Russia
}

\author{
P.S. Nefediev ${ }^{1,2,3}$, J.S. Nefedieva, G.Sh. Farzalieva ${ }^{4}$ \\ ${ }^{1}$ Altai State University, Lenina Avenue, 61, Barnaul 656049 Russia.E-mail:p.nefediev@mail.ru \\ ${ }^{2}$ Tomsk State University, Lenina Avenue, 36, Tomsk 634050 Russia. \\ ${ }^{3}$ Tigirek State Nature Reserve, Nikitina Street, 111, Barnaul 656049 Russia. \\ ${ }^{4}$ Perm State University, Bukireva Street, 15, Perm 614600 Russia.E-mail: fgsh@psu.ru
}

ABSTRACT. Based on a small material from the Republic of Khakassia, central Siberia, Russia, new information on the myriapod fauna is presented. Two lithobiid species, Lithobius (Ezembius) ostiacorum Stuxberg, 1876 and L. (Monotarsobius) nordenskioeldii Stuxberg, 1876, are recorded from Khakassia for the first time. Both the genus Teleckophoron Gulička, 1972 and its sole species T. montanum Gulička, 1972, as well as the family Kirkayakidae they belong to, are also new to the millipede fauna of Khakassia. The distributions of all species encountered are mapped.

How to cite this article: Nefediev P.S., Nefedieva J.S., Farzalieva G.Sh. 2021. New data on the myriapod fauna (Myriapoda: Chilopoda, Diplopoda) of the Republic of Khakassia, central Siberia, Russia // Invert. Zool. Vol.18. No.1. P.36-46. doi: 10.15298/invertzool. 18.1 .04

KEY WORDS: geophilomorph centipedes, lithobiomorph centipedes, millipedes, fauna, new records, Siberia.

\section{Новые сведения о фауне многоножек (Myriapoda: Chilopoda, Diplopoda) Республики Хакасия, центральная Сибирь, Россия}

\section{П.С. Нефедьев ${ }^{1,2,3}$, Ю.С. Нефедьева, Г.Ш. Фарзалиева ${ }^{4}$}

\footnotetext{
${ }^{I}$ Алтайский государственный университет, проспект Ленина, 61, Барнаул 656049 Россия. E-mail: p.nefediev@mail.ru

${ }^{2}$ Томский государственный университет, проспект Ленина, 36, Томск 634050 Россия.

${ }^{3}$ Государственный природный заповедник «Тигирекский», улииа Никитина, 111, Барнаул 656049 Россия.

${ }^{4}$ Пермский государственный университет, улииа Букирева, 15, Пермь 614600 Россия. E-mail:fgsh@psu.ru
}

РЕЗЮМЕ. По небольшому материалу из Республики Хакасия (центральная Сибирь, Россия) приводится новая информация о фауне многоножек. Два вида костянок, Lithobius (Ezembius) ostiacorum Stuxberg, 1876 и L. (Monotarsobius) nordenskioeldii Stuxberg, 1876, впервые отмечены в Хакасии. Род Teleckophoron Gulička, 1972 с единственным видом T. montanum Gulička, 1972, а также семейство Kirkayakidae, к которому они принадлежат, также являются новыми для фауны многоножек Хакасии. Для всех видов выполнено картирование находок в исследуемом регионе. 
Как цитировать эту статью: Nefediev P.S., Nefedieva J.S., Farzalieva G.Sh. 2021. New data on the myriapod fauna (Myriapoda: Chilopoda, Diplopoda) of the Republic of Khakassia, central Siberia, Russia // Invert. Zool. Vol.18. No.1. P.36-46. doi: 10.15298/ invertzool.18.1.04

КЛЮЧЕВЫЕ СЛОВА: многоножки-земЛянки, многоножки-костянки, двупарноногие многоножки, фауна, новые находки, Сибирь.

\section{Introduction}

The Republic of Khakassia is located in the central part of the Asian continent in the south of central Siberia. It spans about $460 \mathrm{~km}$ north to south and $200 \mathrm{~km}$ west to east (in its widest part), bordering on the Krasnoyarsk Province in the north, east and southeast, the Republic of Tyva in the south, the Republic of Altai in the southwest, and the Kemerovo Area in the west.

The Khakassian Republic is part of the Altai-Sayan region, being characterized by a pronounced variety of physical and geographical structures, as well as a highly diverse vegetation (Kostyakova et al., 2018). The landscape and orographic structures of the Republic vary considerably and range from its plain (Minusinskaya and Chulymo-Yeniseiskaya depressions) to montane parts, i.e. the eastern slopes of the Kuznetskii Alatau and the Abakanskii Mountain Range, and the northern slopes of the Western Sayan Mountains (Semenov, Lysanova, 2016). The study area is subjected to a continental climate, with short summers and long and cold winters, with the average annual temperature of $+0.8^{\circ} \mathrm{C}$. January is the coldest month ($\left.18.6^{\circ} \mathrm{C}\right)$, while July is the warmest month $\left(+18.7^{\circ} \mathrm{C}\right)$. The highest amount of annual precipitation (75-90\%) falls in summer, the greatest annual level being confined to the mountains (up to $2000 \mathrm{~mm}$ ), while the leeward slopes and interior depressions receive only $250 \mathrm{~mm}$. July is the most humid month (67-82 $\mathrm{mm})$, while both February and March are the driest ones (4$8 \mathrm{~mm}$ ) (Kostyakova et al., 2018). Most of the watercourses in the Republic of Khakassia belong to the Yenisei River Basin, the Abakan River being the major tributary, while the northwestern part of the study area pertains to the $\mathrm{Ob}$ River Basin, the Tom, Belyi Iyus, Chiornyi
Iyus, and Chulym rivers being involved. The vegetation of this territory is characterized by Pinus sylvestris L. and Larix sibirica Ledeb. forests, while the steppe belt supports forbgrass-sedge meadows (Kostyakova et al., 2018).

To date, based on literature data (Shear, 1990; Mikhaljova, 1993, 2000, 2017; Mikhaljova, Golovatch, 2001; Mikhaljova, Nefediev, 2003; Mikhaljova, Marusik, 2004; Nefediev, Nefedieva, 2017; Nefediev, 2018a, b, 2019a; Nefediev, Farzalieva, 2020), at least 19 species of Myriapoda are known to occur in the Republic of Khakassia, representing 11 genera, 7 families, and 5 orders. The present paper provides new records and a primary inventory of both Chilopoda and Diplopoda of the study area.

The distribution maps were composed using QGIS 3.14.15-Pi.

The material treated here has been deposited in the collections of the Altai State University, Barnaul, Russia (ASU), the Perm State University, Perm, Russia (PSU), and the Zoological Museum of the Lomonosov Moscow State University, Moscow, Russia (ZMUM), as indicated below.

\section{Taxonomic part}

Class Chilopoda

Order Geophilomorpha

Family GEOPHILIDAE

Arctogeophilus macrocephalus

Folkmanová et Dobroruka, 1960

Map 1.

MATERIALEXAMINED. $10^{\top}$ (ASU), Russia, south of central Siberia, Republic of Kha- 


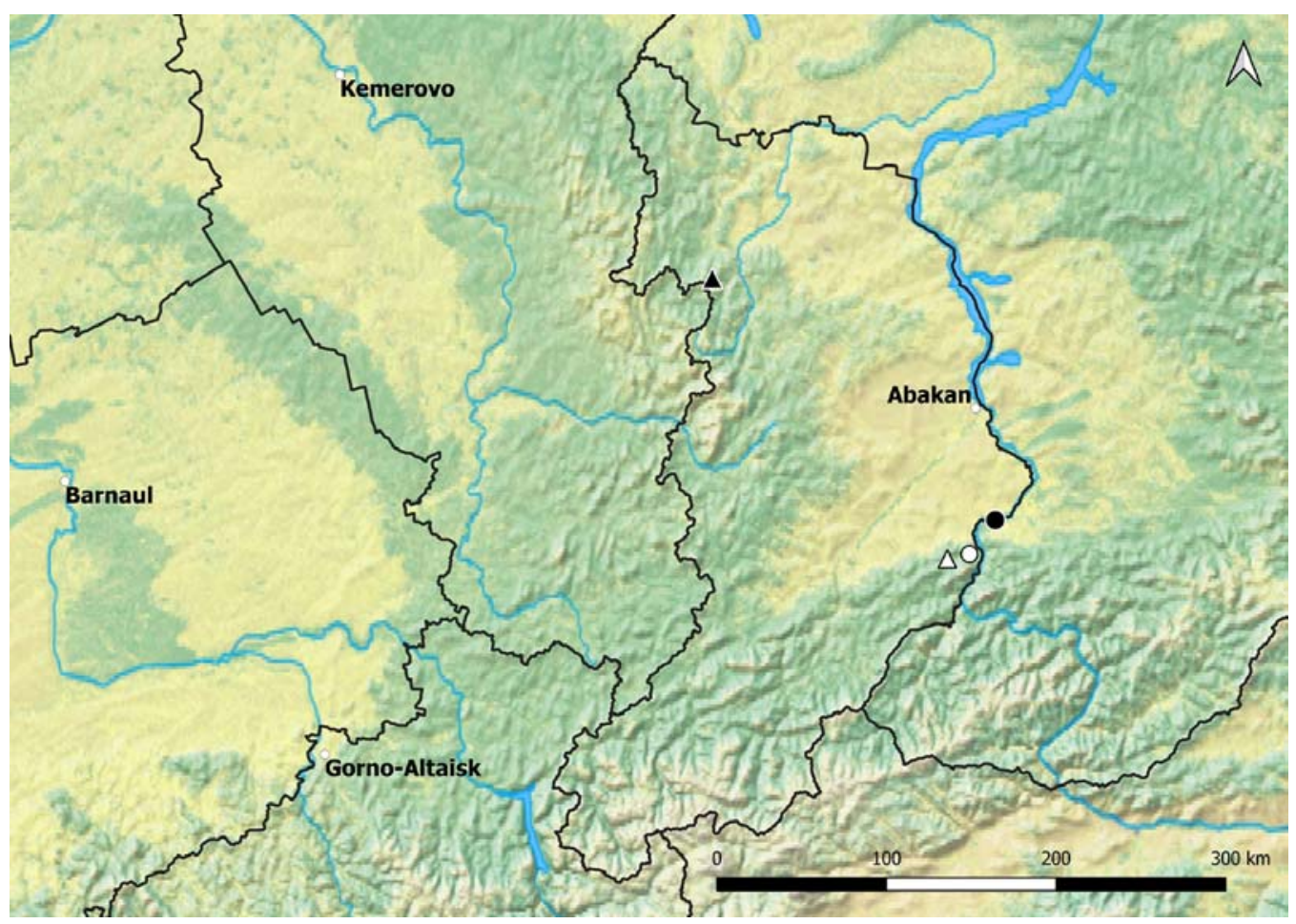

Map 1. Distribution of Arctogeophilus macrocephalus (circle) and Schizoturanius tabescens (triangle) in the Republic of Khakassia. Previously known localities marked in black, new records given in white. Карта 1. Распространение Arctogeophilus macrocephalus (круг) и Schizoturanius tabescens (треугольник) в Республике Хакасия. Черным отмечены ранее известные места находок, новые находки отмечены белым.

kassia, Beya District, ca. 6 air-km W of Maina, Ui River valley, $52.987139^{\circ} \mathrm{N}, 91.391917^{\circ} \mathrm{E}$, Pinus sylvestris forest, ca. $400 \mathrm{~m}$ a.s.1., in litter, 21.IX.2019, leg. E.Yu. Shuryshev.

DISTRIBUTION. Originally described by Folkmanová \& Dobroruka (1960) from the European part of Russia (Tatarstan Republic), $A$. macrocephalus is highly widespread from European Russia through Siberia and eastern Kazakhstan to the inland Russian Far East and Sakhalin Island (Zalesskaja et al., 1982; Volkova, 2016; Dyachkov, Tuf, 2019). In Siberia, this species has hitherto been recorded from the Kemerovo and Tomsk areas, the Altai and Khakassian republics, and the Altai and Krasnoyarsk provinces (Byzova, Chadaeva, 1965; Zalesskaja et al., 1982; Vorobiova, 1999; Rybalov, 2002; Vorobiova et al., 2002; Nefediev et al., 2017a, c, 2018; Nefediev, 2019a).
ORDER Lithobiomorpha

Family LITHOBIIDAE

\section{Lithobius (Ezembius) ostiacorum \\ Stuxberg, 1876 Map 2.}

MATERIAL EXAMINED (all Russia, south of central Siberia, Republic of Khakassia). 1 (PSU-1254), Shira District, near Efremkino, $54.469709^{\circ} \mathrm{N}, 89.445864^{\circ} \mathrm{E}$, ca. $480 \mathrm{~m}$ a.s.1., VII-VIII.2004, leg. E.V. Miroshnichenko; 1 $\sigma^{7}, 2$ juv. (ZMUM), Beya District, near Novonikolaevka, $53.194961^{\circ} \mathrm{N}, 91.295908^{\circ} \mathrm{E}$, site 42 , Padus avium, ca. $310 \mathrm{~m}$ a.s.l., soil samples, 25.V.1986, collector unknown; 1 , 1 juv. (PSU1465), same District, ca. 6 air-km W of Maina, Ui River valley, $52.987139^{\circ} \mathrm{N}, 91.391917^{\circ} \mathrm{E}$, 


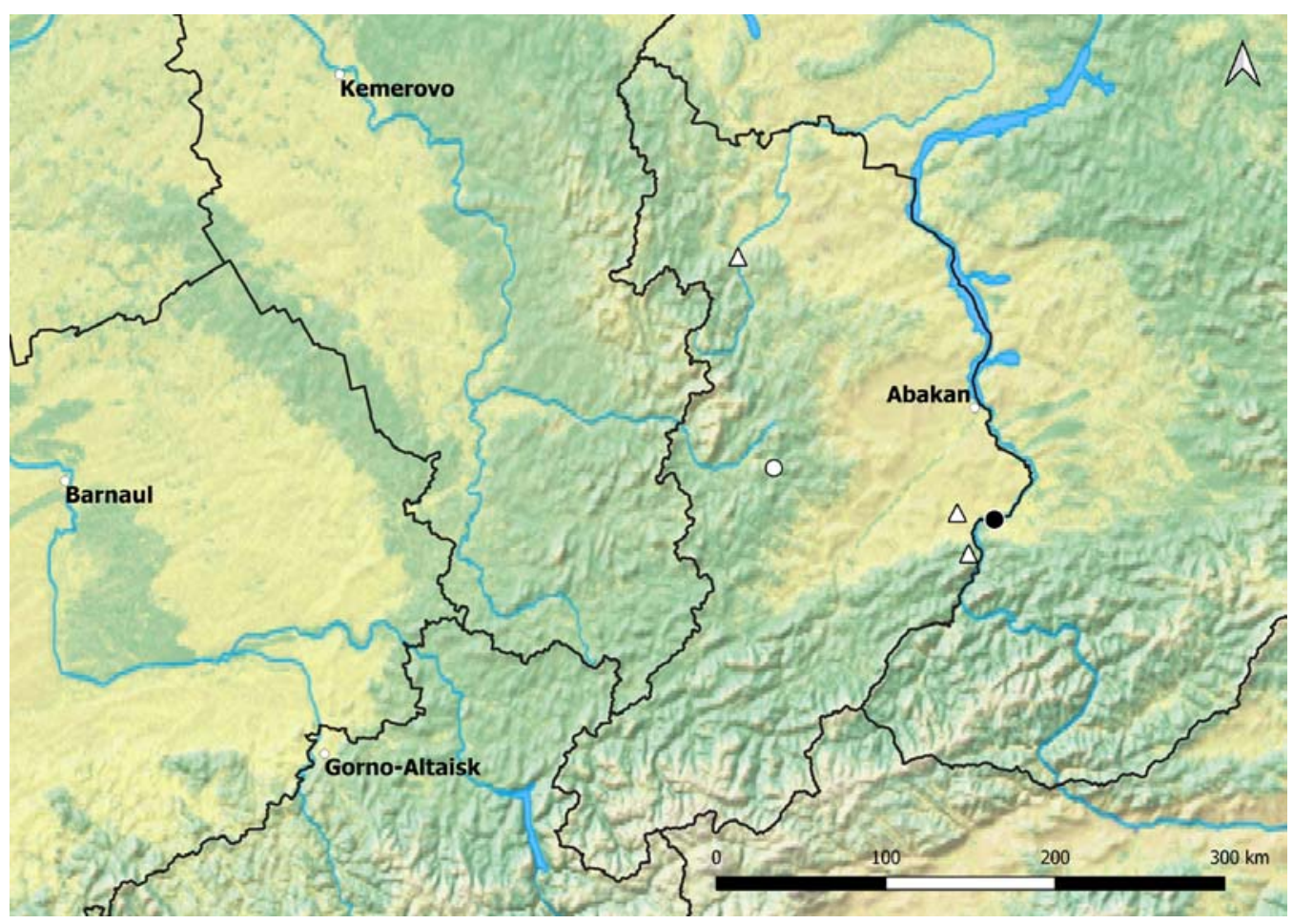

Map 2. Distribution of Lithobius (Ezembius) ostiacorum (triangle) and L. (E.) princeps (circle) in the Republic of Khakassia. Previously known localities marked in black, new records given in white.

Карта 2. Распространение Lithobius (Ezembius) ostiacorum (треугольник) и L. (E.) princeps (круг) в Республике Хакасия. Черным отмечены ранее известные места находок, новые находки отмечены белым.

Pinus sylvestris forest, ca. $400 \mathrm{~m}$ a.s.l., in litter, 21.IX.2019, leg. E.Yu. Shuryshev.

DISTRIBUTION. Originally described by Stuxberg $(1876 \mathrm{a}, \mathrm{b})$ from the Yenisei River region (Krasnoyarsk Province), this species was redescribed by Eason (1976) using Stuxberg's type material. Being widely distributed in Siberia, Lithobius (E.) ostiacorum has hitherto been known from the Irkutsk and Kemerovo areas, the Altai and Krasnoyarsk provinces, and the Republic of Altai (Zalesskaja, 1978; Nefediev et al., 2017a, 2018, 2020b; Nefediev, Farzalieva, 2020). The southernmost records of this species are known from northern Mongolia (Poloczek et al., 2016, 2017).

REMARKS. This species is formally new to the fauna of the Republic of Khakassia.

\section{Lithobius (Ezembius) princeps}

Stuxberg, 1876 Map 2.

MATERIAL EXAMINED. 1 ○ (PSU1470), Russia, south of central Siberia, Republic of Khakassia, Askiz District, ca. 3 air-km SE of Nankhchul, Askiz River valley, near mouth of Portal River, $53.418861^{\circ} \mathrm{N}, 89.749639^{\circ} \mathrm{E}$, Pinus sylvestris forest with Abies sibirica and Betula pendula, ca. $650 \mathrm{~m}$ a.s.l., in litter, 1.VIII.2019, leg. A.P. Pavlov.

DISTRIBUTION. This species was originally described by Stuxberg (1876a, b) from near the Podkamennaya Tunguska River (Krasnoyarsk Province), later redescribed by Eason (1976) using Stuxberg's type material. This species was later recorded from eastern Kaza- 


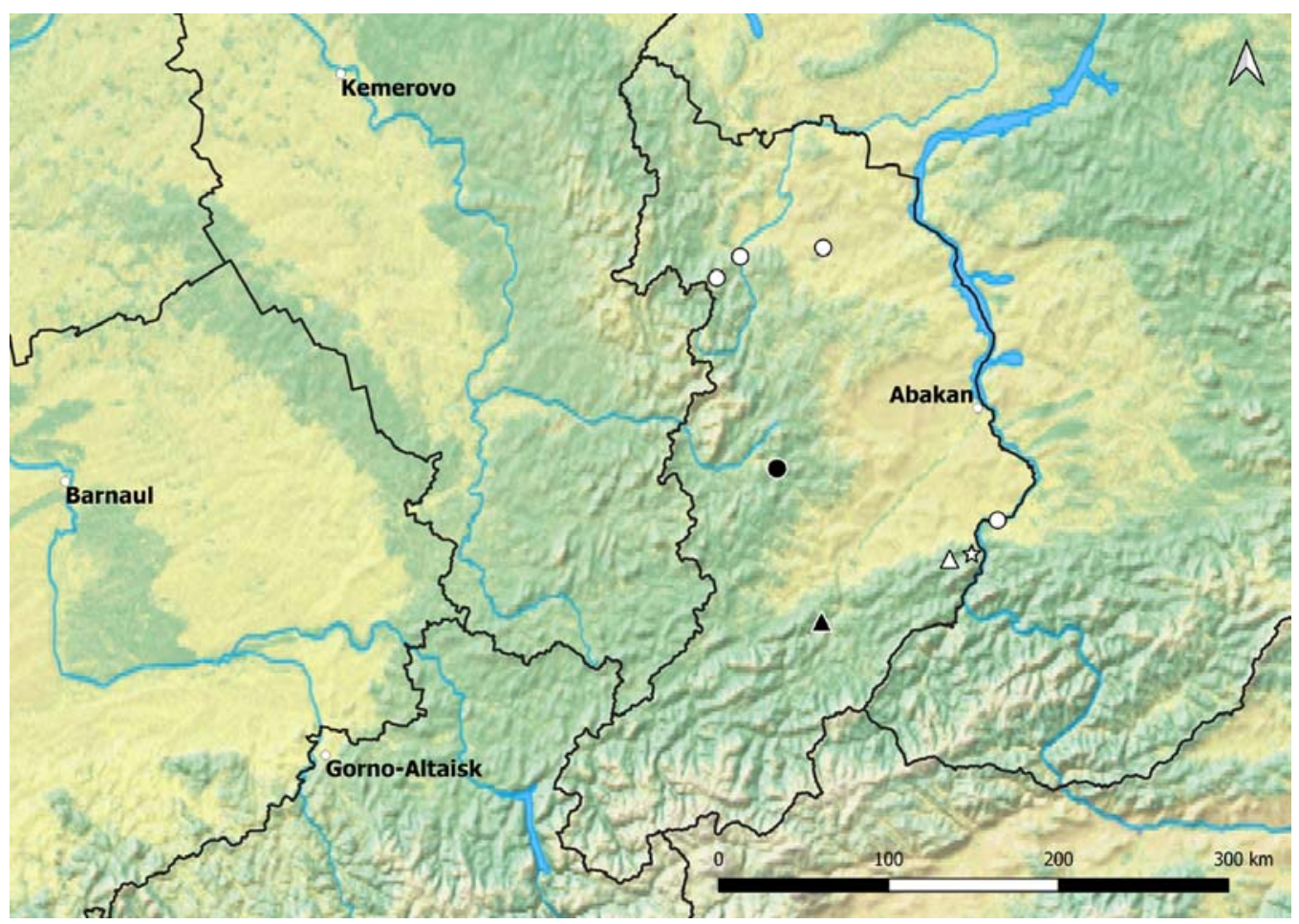

Map 3. Distribution of Lithobius (Monotarsobius) fugax (circle), L. (M.) nordenskioeldii (asterisk) and Sibiriulus profugus (triangle) in the Republic of Khakassia. Previously known localities marked in black, new records given in white.

Карта 3. Распространение Lithobius (Monotarsobius) fugax (круг), L. (M.) nordenskioeldii (звездочка) и Sibiriulus profugus (треугольник) в Республике Хакасия. Черным отмечены ранее известные места находок, новые находки отмечены белым.

khstan (Tuf, 2007; Tuf et al., 2010; Dyachkov, 2017, 2019), the Tyumen and Omsk areas, and the Republic of Khakassia, all Siberia (Sergeeva, 2010; Bukhkalo et al., 2014; Nefediev et al., 2017b; Nefediev, Farzalieva, 2020).

\section{Lithobius (Monotarsobius) fugax Stuxberg, 1876 Map 3.}

MATERIAL EXAMINED(all Russia, south of central Siberia, Republic of Khakassia). 1 ㅇ (PSU-733), Shira District, ca. 3 air-km NW of Kommunar, Bolnichnyi Stream valley, $54.364722^{\circ} \mathrm{N}, 89.249167^{\circ} \mathrm{E}$, bottom of rocky scree, ca. $840 \mathrm{~m}$ a.s.1., 30.VII.1999; $1 \mathrm{O}^{7}, 2$ 우 (PSU-734), same District, ca. 10 air-km E of
Shira, $54.513889^{\circ} \mathrm{N}, 90.143056^{\circ} \mathrm{E}$, bank of Lake Shira, piles of stones and boulders, ca. $355 \mathrm{~m}$ a.s.1., 3.VIII.1999, all leg. P.S. Nefediev; 1 (PSU-1255), same District, near Efremkino, $54.469709^{\circ} \mathrm{N}, 89.445864^{\circ} \mathrm{E}$, ca. $480 \mathrm{~m}$ a.s.l, VII-VIII.2004, leg. E.V. Miroshnichenko; 6 $\sigma^{\top} \sigma^{\top}, 1$ (PSU-816), Altaiskii District, near Ochury, Ochurskii Bor, 53.159306 N, 91. $609972^{\circ} \mathrm{E}$, Pinus sylvestris forest, ca. $300 \mathrm{~m}$ a.s.1., 30.IX.2008, leg. D.I. Pogrebnyak.

DISTRIBUTION. Originally described by Stuxberg (1876a, b) from the Yenisei River region(Krasnoyarsk Province), this species was later redescribed by Eason (1976) with lectotype designation, and it was synonymized with Monotarsobius kaszabi Loksa, 1965, the latter species described from Mongolia. Lithobius 
(M.) fugax was later recorded from the Kemerovo Area and the Republic of Khakassia, both Siberia (Nefediev et al., 2020b; Nefediev, Farzalieva, 2020).

\section{Lithobius (Monotarsobius) nordenskioeldii Stuxberg, 1876 Map 3.}

MATERIAL EXAMINED. 1 ○ (PSU1466), Russia, south of central Siberia, Republic of Khakassia, Beya District, ca. $6 \mathrm{~km}$ W of Maina, Ui River valley, $52.987139^{\circ} \mathrm{N}, 91$. $391917^{\circ} \mathrm{E}$, Pinus sylvestris forest, ca. $400 \mathrm{~m}$ a.s.1., in litter, 21.IX.2019, leg. E.Yu. Shuryshev.

DISTRIBUTION. Originally described by Stuxberg $(1876 a, b)$ from the Yenisei River region (Krasnoyarsk Province) and later redescribed by Eason (1976) using Stuxberg's type material. This species was later recorded from the Republic of Altai, the Altai Province, and the Irkutsk Area (Nefediev et al., 2017a, 2018, 2020a; Nefediev, Farzalieva, 2020).

REMARKS. This is the first record of $L$. (M.) nordenskioeldii in the Republic of Khakassia.

\section{Class Diplopoda}

Order Julida

Family JULIDAE

Sibiriulus profugus (Stuxberg, 1876) Map 3.

MATERIAL EXAMINED. $1 \sigma^{\gamma}$ (ASU), Russia, south of central Siberia, Republic of Khakassia, Beya District, ca. 4 air-km WSW of Bogoslovka, Ui River valley, $52.962222^{\circ} \mathrm{N}$, $91.206111^{\circ} \mathrm{E}$, mixed forest with Pinus sylvestris, Picea obovata, Abies sibirica and Betula pendula, ca. $600 \mathrm{~m}$ a.s.1., 22.VII.2019, leg. E.Yu. Shuryshev.

DISTRIBUTION. This species was originally described as Iulus profugus from the area between Tomsk and Kansk (Stuxberg 1876a, b), later transferred to Sibiriulus Gulička, 1963
(Lokšina, Golovatch, 1979), redescribed based on material from both the Novosibirsk Area and the Republic of Khakassia (Mikhaljova, 1993), and finally it was sunken as a senior subjective synonym of Cylindroiulus (Sibiriulus) dentiger Gulička, 1963 (Mikhaljova, 2002), a form described from the Kemerovo Area (Gulička, 1963). Being the most widespread species of Sibiriulus, this species is presently known from the Tomsk, Novosibirsk and Kemerovo areas, the Altai and Krasnoyarsk provinces, the republics of Altai and Khakassia (Stuxberg, 1876a, b; Gulička, 1963; Byzova, Chadaeva, 1965; Mikhaljova, 1993, 2002, 2004, 2017; Mikhaljova, Golovatch, 2001; Babenko et al., 2009; Nefediev, 2002a, b, 2018b; Mikhaljova, Nefediev, 2003; Mikhaljova et al., 2007, 2014; Nefediev, Nefedieva, 2007a, b, c, 2011, 2017).

\section{Family NEMASOMATIDAE}
Orinisobates sibiricus (Gulička, 1963) Map 4.

MATERIAL EXAMINED (all Russia, south of central Siberia, Republic of Khakassia). 14 $\sigma^{7} \sigma^{7}, 19$ 우, 2 juv. (ASU), Ust-Abakan District, ca. 12 air-km W of Ust-Byur, right board of Uibat River valley, $53.825765^{\circ} \mathrm{N}$, $90.052647^{\circ} \mathrm{E}$, Pinus sylvestris forest with Larix sibirica and Betula pendula, ca. $705 \mathrm{~m}$ a.s.l., in litter, 17.VII.2012, leg. A.B. Medvedev; $2 O^{\top} \sigma^{\top}$, 6 우 (ASU), same locality, in litter, 18.VII.2012, leg. A.P. Pavlov; $3 \sigma^{7} \sigma^{7}, 2$, $\circ, 3$ exuviae (ASU), Askiz District, ca. 3.5 air-km SE of Nankhchul, Askiz River valley, near mouth of Portal River, $53.419057^{\circ} \mathrm{N}, 89.756044^{\circ} \mathrm{E}$, edge of Picea obovata, Larix sibirica and Betula pendula forest, under stones, ca. $675 \mathrm{~m}$ a.s.1., 4.VIII.2018, leg. O.A. Makarenko; $1+$ (ASU), near same locality, $53.419056^{\circ} \mathrm{N}, 89.756056^{\circ} \mathrm{E}$, under stones, in litter, 21.VI.2019; $1 \mathrm{O}^{\top}$ (ASU), same locality, under stones, in litter, 1.VIII.2020, all leg. S.V. Dragan; $10^{\top}$ (ASU), Beya District, ca. 6 air-km $\mathrm{W}$ of Maina, Ui River valley, $52.987139^{\circ} \mathrm{N}$, $91.391917^{\circ} \mathrm{E}$, Pinus sylvestris forest, ca. $400 \mathrm{~m}$ a.s.1., in litter, 21.IX.2019, leg. E.Yu. Shuryshev. 


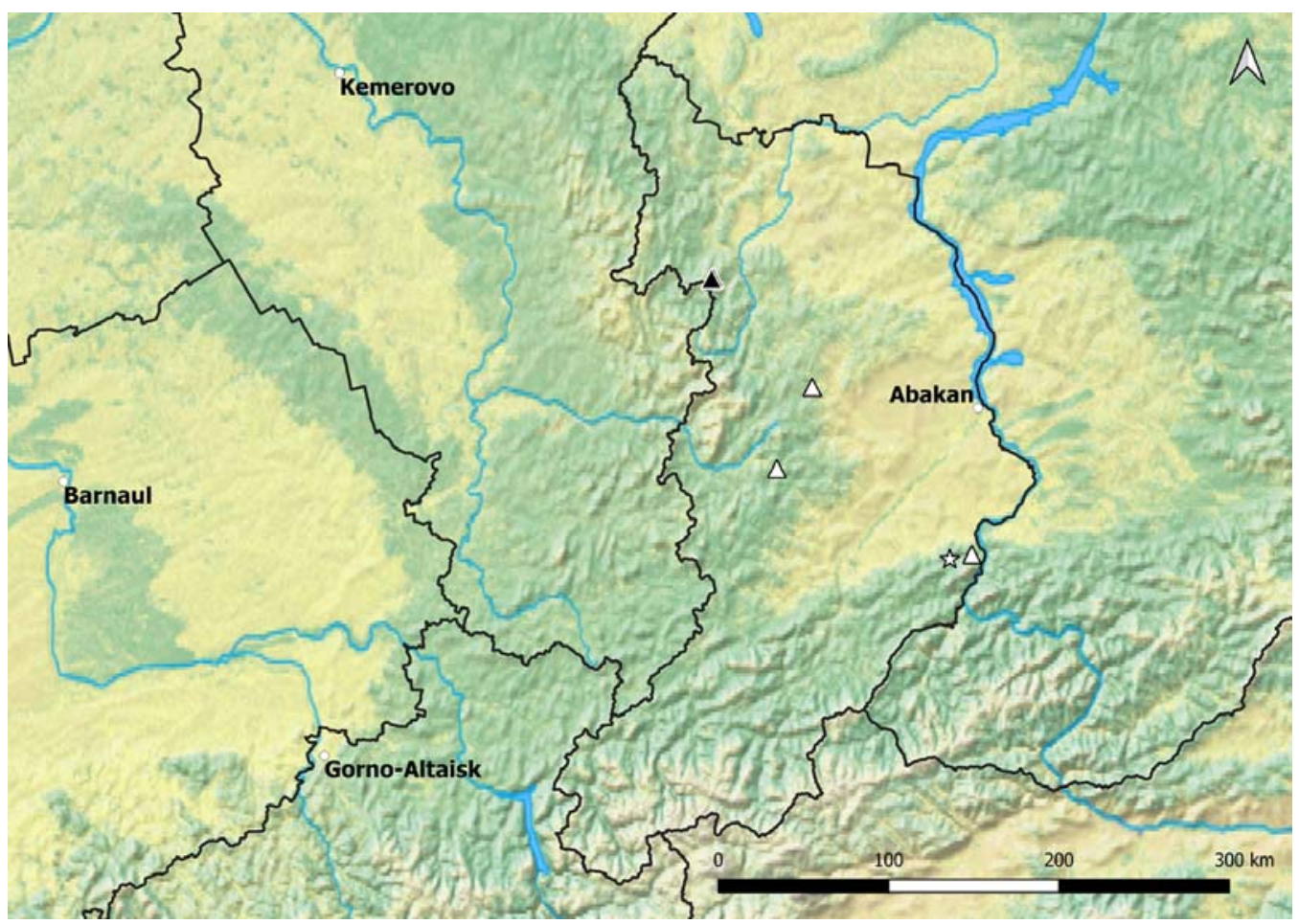

Map 4. Distribution of Orinisobates sibiricus (triangle) and Teleckophoron montanum (asterisk) in the Republic of Khakassia. Previously known localities marked in black, new records given in white.

Карта 4. Распространение Orinisobates sibiricus (треугольник) и Teleckophoron montanum (звездочка) в Республике Хакасия. Черным отмечены ранее известные места находок, новые находки отмечены белым.

DISTRIBUTION. Originally described as Isobates sibiricus by Gulička (1963) from the Kemerovo Area, this species was later transferred first to the subgenus Orinisobates (Gulička, 1972), and finally to the genus Orinisobates (Lokšina, Golovatch, 1979). The distribution of O. sibiricus is mostly confined to Siberia, Russia, viz. the Kemerovo and Irkutsk areas, the republics of Khakassia, Altai and Tyva, and the Krasnoyarsk, Altai and Zabaikalskii provinces (Gulička, 1963, 1972; Byzova, Chadaeva, 1965; Enghoff, 1985; Mikhaljova, 1993, 2002, 2004, 2016, 2017; Mikhaljova, Golovatch, 2001; Mikhaljova, Nefediev, 2003; Nefediev, Nefedieva, 2006, 2007a, b, 2013; Nefedieva, Nefediev, 2008; Nefediev et al., 2014, 2018; Nefedieva et al., 2015; Nefediev, 2018b). This species is also known from the Eastern Kazakhstan and
Almaty areas (both Kazakhstan), and the Talas Area (Kyrgyzstan) (Enghoff, 1985).

Order Chordeumatida

$$
\text { Family KIRKAYAKIDAE }
$$

Teleckophoron montanum Gulička, 1972 Map 4.

MATERIAL EXAMINED. $3 \sigma^{\top} \sigma^{\top}, 1$ \% (ASU), Russia, south of central Siberia, Republic of Khakassia, Beya District, ca. 4 air-km WSW of Bogoslovka, Ui River valley, 52. $962222^{\circ} \mathrm{N}, 91.206111^{\circ} \mathrm{E}$, mixed forest with Pinus sylvestris, Picea obovata, Abies sibirica and Betula pendula, ca. 600 ma.s.1.,22.VII.2019, leg. E.Yu. Shuryshev. 
DISTRIBUTION. This species was originally described by Gulička (1972) from the environs of Lake Teletskoye, Republic of Altai, with the type material deposited in the personal collection of the author in Bratislava, Slovakia. The original description was too incomplete, and the illustrations were very schematic. Upon the request of S.I. Golovatch, the holotype was returned to Russia, but without gonopods. According to those reasons, T. montanum was listed among nomina dubia for a long time. New records of this species from the southern part of the Krasnoyarsk Province finally allowed for a redescription to be published(Mikhaljova, Golovatch, 2001).

REMARKS. The above record of $T$. montanum is formally new to the Republic of Khakassia.

Order Polydesmida

Family POLYDESMIDAE

\section{Schizoturanius tabescens (Stuxberg, 1876) Map 1.}

MATERIAL EXAMINED. 1 (ASU), Russia, south of central Siberia, Republic of Khakassia, Beya District, ca. 4 air-km WSW of Bogoslovka, Ui River valley, $52.962222^{\circ} \mathrm{N}$, $91.206111^{\circ} \mathrm{E}$, mixed forest with Pinus sylvestris, Picea obovata, Abies sibirica and Betula pendula, ca. $600 \mathrm{~m}$ a.s.1., 22.VII.2019, leg. E.Yu. Shuryshev.

DISTRIBUTION. Originally described as Polydesmus tabescens by Stuxberg (1876a, b) from the Yenisei River region (Krasnoyarsk Province), this species was later transferred to Schizoturanius Verhoeff, 1931 (Mikhaljova, 1993), and then proven to be a senior subjective synonym of Turanodesmus salairicus Gulička, 1963 (Mikhaljova, Marusik, 2004). Schizoturanius tabescens was later recorded from the Tomsk, Novosibirsk, Kemerovo, Tyumen and Irkutsk areas, the Altai Province, and the republics of Altai and Khakassia (Byzova, Chadaeva, 1965; Mikhaljova, 1993, 2004, 2013, 2017; Vorobiova, 1999; Mikhaljova, Golovatch, 2001;
Nefediev, 2001, 2002a, b, c, d, 2019b; Rybalov, 2002; Rybalov, Vorobiova, 2002; Vorobiova et al., 2002; Mikhaljova, Nefediev, 2003; Nefediev, Nefedieva, 2005, 2006, 2007a, b, c, 2011, 2012a, b, 2013, 2017; Nefedieva, Nefediev, 2008; Babenko et al., 2009; Bukhkalo et al., 2014; Nefedieva et al., 2015).

\section{Conclusions}

At present, the myriapod fauna of the Republic of Khakassia comprises at least 22 species from 12 genera, 8 families and 5 orders: Geophilus proximus C.L. Koch, 1847, Arctogeophilus macrocephalus Folkmanová et Dobroruka, 1960, Escaryus japonicus Attems, 1927, E. koreanus Takakuwa, 1937, Lithobius (Chinobius) opinatus (Zalesskaja, 1978), L. (Ezembius) ostiacorum Stuxberg, 1876*, L. (E.) princeps Stuxberg, 1876, L. (Monotarsobius) curtipes C.L. Koch, 1847, L. (M.) fugax Stuxberg, 1876, L. (M.) nordenskioeldii Stuxberg, $1876^{*}$, L. (M.) worogowensis Eason, 1976, Julus ghilarovi Gulička, 1963, Pacifiiulus amurensis (Gerstfeldt, 1859), Sibiriulus profugus (Stuxberg, 1876), Orinisobates sibiricus (Gulička, 1963), Teleckophoron montanum Gulička, 1972*, Altajosoma bakurovi (Shear, 1990), A. deplanatum (Stuxberg, 1876), A. kemerovo (Shear, 1990), Shearia khakassica Mikhaljova, 2000, Schizoturanius clavatipes (Stuxberg, 1876), and S. tabescens (Stuxberg, 1876). The first records from the Republic of Khakassia are marked with an asterisk $\left(^{*}\right)$.

The genus Teleckophoron Gulička, 1972, and the family Kirkayakidae it belongs to, are formally new to the Republic of Khakassia.

Acknowledgements. We are sincerely grateful to S.I. Golovatch (Moscow, Russia) who kindly checked the English of an advanced draft. Our deepest gratitude is extended to S.V. Dragan (Abakan, Russia) who provided material collected by his colleagues for the present study. We are indebted to E.V. Mikhaljova (Vladivostok, Russia) and I.H. Tuf (Olomouc, Czech Republic) who kindly reviewed and improved the manuscript. 


\section{References}

Babenko A.S., Nefediev P.S., Nefedieva J.S. 2009. [The fauna and population dynamics of the millipedes (Diplopoda) of the Salair chern taiga] // Vestnik Tomskogo gosudarstvennogo universiteta, Seriya Biologiya. Vol.319. P.182-185 [in Russian].

Bukhkalo S.P., Galitch D.E., Sergeeva E.V., Vazhenina N.V. 2014. [Synopsis of the invertebrate fauna of the southern taiga in western Siberia (basin of the Lower Irtysh)]. Moscow: KMK Scientific Press. 189 p. [In Russian]

Byzova Yu.B., Chadaeva Z.V. 1965. [Comparative characteristics of soil fauna of various associations in an Abies sibirica forest (Kemerovo Area)] // Zoologicheskii Zhurnal. T.44. No.3. P.331-339 [in Russian, with English summary].

Dyachkov Yu.V. 2017. [The first data on the centipede (Chilopoda: Geophilomorpha; Lithobiomorpha) fauna of the Katun Biosphere State Nature Reserve, Altai Mts] // Ukrainian Journal of Ecology. Vol.7. No.4. P.453-456 [in Russian, with English summary].

Dyachkov Yu.V. 2019. New data on lithobiomorph centipedes (Chilopoda: Lithobiomorpha: Anopsobiidae, Henicopidae, Lithobiidae) from Kazakhstan // Arthropoda Selecta. Vol.28. No.1. P.8-20.

Dyachkov Yu.V., Tuf I.H. 2019. New data on the family Geophilidae Leach, 1815 (Chilopoda: Geophilomorpha) from Kazakhstan // Far Eastern Entomologist. No.391. P.24-28.

Eason E.H. 1976. The type specimens and identity of the Siberian species described in the genus Lithobius by Anton Stuxberg in 1876 (Chilopoda: Lithobiomorpha) // Zoological Journal of the Linnean Society. No.58. P.98-127.

Enghoff H. 1985. The millipede family Nemasomatidae with the description of a new genus and a revision of Orinisobates (Diplopoda, Julida) // Entomologica Scandinavica. Vol.16. P.27-67.

Folkmanová B., Dobroruka L.J. 1960. [A contribution to Chilopoda of the USSR] // Zoologicheskii Zhurnal. Vol.39. No.12. P.1811-1818 [in Russian with German summary].

Gulička J. 1963. [New millipedes (Diplopoda) from the USSR. Part 1] // Zoologicheskii Zhurnal. Vol.42. No.4. P.518-524 [in Russian with English summary].

Gulička J. 1972. [New millipedes (Diplopoda) from the USSR. Part 2] // Zoologicheskii Zhurnal. Vol.51. No.1. P.36-45 [in Russian with English summary].

Kostyakova T.V., Touchan R., Babushkina E.A., Belokopytova L.V. 2018. Precipitation reconstruction for the Khakassia region, Siberia, from tree rings // The Holocene. Vol.28. No.3. P.377-385.

Lokšina I.E., Golovatch S.I. 1979. Diplopoda of the USSR fauna // Pedobiologia. Vol.19. P.381-389.

Mikhaljova E.V. 1993. The millipedes (Diplopoda) of Siberia and the Far East of Russia // Arthropoda Selecta. Vol.2. No.2. P.3-36.

Mikhaljova E.V. 2000. Review of the millipede family Diplomaragnidae (Diplopoda: Chordeumatida) // Arthropoda Selecta. Vol.8 (for 1999). No.3. P.153-181.
Mikhaljova E.V. 2002. On some poorly-known millipedes from Siberia (Diplopoda)// Arthropoda Selecta. Vol.10 (for 2001). No.3. P.201-207.

Mikhaljova E.V. 2004. The millipedes (Diplopoda) of the Asian part of Russia. Sofia-Moscow: Pensoft Publ. $292 \mathrm{p}$.

Mikhaljova E.V. 2013. [Endemism of the millipedes (Diplopoda) of the Asian part of Russia]// Izucheniye, sokhraneniye i vosstanovleniye estestvennykh landshaftov. Sbornik statei III Mezhdunarodnoi nauchnoprakticheskoi konferentsii. 7-10 October 2013, Volgograd. Moscow: Planeta Publ. P.220-223 [in Russian].

Mikhaljova E.V. 2016. New species and new records of millipedes (Diplopoda) from the Asian part of Russia // Far Eastern Entomologist. No.316. P.1-25.

Mikhaljova E.V. 2017. [The millipede fauna (Diplopoda) of the Asian part of Russia]. Vladivostok: Dalnauka Publ. 336 p. [In Russian, with English summary]

Mikhaljova E.V., Golovatch S.I. 2001. A review of the millipede fauna of Siberia (Diplopoda) // Arthropoda Selecta. Vol.9 (for 2000). No.2. P.103-118.

Mikhaljova E.V., Marusik Yu.M. 2004. New data on taxonomy and fauna of the millipedes (Diplopoda) from the Russian Far East, Siberia and Mongolia // Far Eastern Entomologist. No.133. P.1-12.

Mikhaljova E.V., Nefediev P.S. 2003. A contribution to the millipede fauna of Siberia (Diplopoda) // Arthropoda Selecta. Vol.11 (for 2002). No.1. P.81-87.

Mikhaljova E.V., Nefediev P.S., Nefedieva J.S. 2007. New data on millipedes of the family Julidae (Diplopoda, Julida) from Altai, Siberia // Zootaxa. Vol.1541. P.57-63.

Mikhaljova E.V., Nefediev P.S., Nefedieva J.S., Sakhnevich M.B., Dyachkov Yu.V. 2014. Review of the millipede genus Sibiriulus Gulièka, 1972, with descriptions of three new species from Altai, Siberia, Russia (Diplopoda, Julida, Julidae) // Zootaxa. Vol.3866. No.1. P.30-52.

Nefediev P.S. 2001. [On the fauna and ecology of Myriapoda in the environs of the village of Smolenskoe, Altai Province] // S.V. Popov (ed.). Landshafty Zapadnoi Sibiri: problemy issledovanii, ekologiya i ratsionalnoye ispolzovaniye. Materialy VII Mezhdunarodnoi mezhvuzovskoi konferentsii, posvyaschionnoi Dnyu Zemli. Biysk: Biysk Pedagogical State University Publ. P.84-86 [in Russian].

Nefediev P.S. 2002a. [Eco-faunistic investigations of myriapods in the Teguldet District, Tomsk Area] // Lomonosov-2002. Materialy Mezhdunarodnoi konfrentsii studentov i molodykh uchionykh. Vol.7. Moscow: Moscow State University Publ. P.40-41 [in Russian].

Nefediev P.S. 2002b. On the Diplopoda fauna of SouthWest Siberia // Abstracts of 12th International Congress of Myriapodology. 28 July - 3 August 2002, Mtunzini, KwaZulu-Natal, South Africa. P.30.

Nefediev P.S. 2002c. [Populations and some ecological peculiarities of myriapods of gray forest soils in the southern of the Tomsk Area] // Biologiya - nauka XXI 
veka. Tezisy 6 Shkoly-konferentsii molodykh uchionykh. Pushchino-on-Oka: Pushchino Scientific Centre RAS Publ. P.138-139 [in Russian].

Nefediev P.S. 2002d. [The fauna and ecology of myriapods (Myriapoda) of a relict lime grove (village of Kuzedeyevo)] // Student i nauchno-tekhnicheskii progress: Biologiya. Materialy XL Mezhdunarodnoi nauchnoi studencheskoi konferentsii. Novosibirsk: Novosibirsk State University Publ. P.35 [in Russian].

Nefediev P.S. 2018a. Julus ghilarovi Gulièka, 1963 s.str.: time to put an end to confusion (Diplopoda: Julida: Julidae) // Arthropoda Selecta. Vol.27. No.4. P.284 292.

Nefediev P.S. 2018b. New records of millipedes of the order Julida (Diplopoda) from Asian Russia and adjacent regions // Far Eastern Entomologist. No.370. P.12-20.

Nefediev P.S. 2019a. New records of geophilomorph centipedes (Chilopoda: Geophilomorpha) from natural and anthropogenic habitats of Siberia // Far Eastern Entomologist. No.380. P.23-28.

Nefediev P.S. 2019b. New records of the millipede genus Schizoturanius Verhoeff, 1931 from the Asian part of Russia (Diplopoda: Polydesmida: Polydesmidae) // Russian Entomological Journal. Vol.28. No.3. P.331339.

Nefediev P.S., Farzalieva G.Sh. 2020. New records of lithobiid centipedes from Siberia, Russia (Chilopoda: Lithobiomorpha: Lithobiidae) // Arthropoda Selecta. Vol.29. No.2. P.185-198.

Nefediev P.S., Nefedieva J.S. 2005. [Seasonal fluctuations of diplopod density in some forests of Western Siberia] // B.R. Striganova (ed.). Ekologicheskoe raznoobrazie pochvennoi bioty i biologicheskaya produktivnost pochv. Materialy dokladov IV (XIV) Vserossiiskoi konferentsii po pochvennoi zoologii. 1-4 February 2005, Tyumen. Tyumen: Tyumen State University Publ. P.177-178 [in Russian].

Nefediev P.S., Nefedieva J.S. 2006. [Regional peculiarities of millipede fauna (Diplopoda) in the south-east of Western Siberia] // V.V. Anyushkin (ed.) Ekologiya Yuzhnoi Sibiri i sopredelnykh territorii. Sbornik materialov X Mezhdenarodnoi shkoly-konferentsii studentov i molodykh uchionykh. Abakan: Khakassian State University Publ. Vol.10. No.1. P.98 [in Russian].

Nefediev P.S., Nefedieva J.S. 2007a. A brief analysis of the biotopic distribution of millipedes (Diplopoda) in the south-east of Western Siberia // A.I. Taskaev (ed.) Lesnoye pochvovedenie: itogi, problem, perspektivy. Tezisy dokladov Mezhdunarodnoi nauchnoi konferentsii. 4-11 September 2007, Syktyvkar. Syktyvkar: Institute of Biology, Komi Scientific Center, Ural Division of RAS Publ. P.139-140.

Nefediev P.S., Nefedieva J.S. 2007b. [Biogeographical characteristic of the millipede fauna in the southeast of Western Siberia] // G.P. Ostroverkhova (ed.) Bioraznoobrazie bespozvonochnykh zhivotnykh. Sbornik materialov II Vserossiiskoi shkoly-seminara s mezhdunarodnym uchastiem. 24-26 October 2007, Tomsk. Tomsk: Deltaplan Publ. P.159-164 [in Russian].
Nefediev P.S., Nefedieva J.S. 2007c. [Seasonal dynamics of locomotor activity of millipedes (Diplopoda) in forests of Western Siberia] // V.N. Kazin (ed.). Ekologicheskie problemy unikalnykh prirodnykh i antropogennykh landshaftov. Sbornik materialov Vserossiiskoi nauchno-prakticheskoi konferentsii. 29 November 2007, Yaroslavl. Yaroslavl: Yaroslavl State University Publ. P.98-103 [in Russian].

Nefediev P.S., Nefedieva J.S. 2011. [Millipedes (Diplopoda) of green plantations of the city of Tomsk and its suburbs]//Kontseptualnye i prikladnye aspekty nauchnykh issledovanii $\mathrm{v}$ oblasti zoologii bespozvonochnykh. Sbornik materialov III Vserossiiskoi shkolyseminara s mezhdunarodnym uchastiem, posvyaschionnoi 120-letiyu so dnya rozhdeniya Rostislava Petrovicha Berezhkova (1891-1961). 24-27 October 2011, Tomsk. Tomsk: Agraf-Press Publ. P.100-102 [in Russian].

Nefediev P.S., Nefedieva J.S. 2012a. [Some peculiarities of the distribution of millipedes (Diplopoda) along a soil profile in the south-taiga and small-leaved forests of Western Siberia] // Izvestiya Altaiskogo gosudarstvennogo universiteta, Biologicheskie nauki. Vol.3(75). No.1. P.49-54 [in Russian, with English summary].

Nefediev P.S., Nefedieva J.S. 2012b. [Some peculiarities of the seasonal dynamics of sex-age structure in millipede populations (Diplopoda) in the southern taiga and small-leaved forests of Western Siberia] // Izvestiya Altaiskogo gosudarstvennogo universiteta, Biologicheskie nauki. Vol.3(75). No.2. P.46-48 [in Russian, with English summary].

Nefediev P.S., Nefedieva J.S. 2013. [Biodiversity and ecology of millipedes in the environs of Lake Teletskoye (Diplopoda)] // Izvestiya Altaiskogo gosudarstvennogo universiteta, Biologicheskie nauki. Vol.3(79). No.1. P.86-87 [in Russian, with English summary].

Nefediev P.S., Nefedieva J.S. 2017. New data on the millipede fauna of the Russian Altais, southwestern Siberia (Diplopoda) // Arthropoda Selecta. Vol.26. No.4. P.288-296.

Nefediev P.S., Dyachkov Yu.V., Nefedieva, J.S. 2014. Fauna and ecology of millipedes (Diplopoda) in the Tigirek State Nature Reserve, Russian Altai // I.H. Tuf, K. Tajovský (eds.). 16th International Congress of Myriapodology. Book of Abstracts. Institute of Soil Biology, BC ASCR \& Faculty of Science, Palacký University, Olomouc. P.63.

Nefediev P.S., Farzalieva G.Sh., Efimov D.A. 2020a. New data on lithobiomorph centipedes (Chilopoda, Lithobiomorpha) from anthropogenic habitats of Siberia // Far Eastern Entomologist. No.418. P.9-14.

Nefediev P.S., Farzalieva G.Sh., Tuf I.H. 2017a. A preliminary review of the fauna of the Altai State Nature Biosphere Reserve, southwestern Siberia, Russia (Chilopoda: Lithobiomorpha, Geophilomorpha) // Arthropoda Selecta. Vol.26. No.3. P.217-224.

Nefediev P.S., Farzalieva G.Sh., Tuf I.H., Efimov D.A. 2020b. The first records of lithobiid centipedes 
(Chilopoda: Lithobiomorpha: Lithobiidae) from the Kemerovo Area, southwestern Siberia, Russia // Invertebrate Zoology. Vol.17. No.1. P.36-43.

Nefediev P.S., Farzalieva G.Sh., Tuf I.H., Nedoev Kh.Kh., Niyazov S.T. 2018. Millipede and centipede assemblages on the northern and southern slopes of the lowland Altais, southwestern Siberia, Russia (Diplopoda, Chilopoda) // P. Stoev, G.D. Edgecombe (eds.). Proceedings of the 17th International Congress of Myriapodology, Krabi, Thailand. ZooKeys. Vol.741. P.219-254.

Nefediev P.S., Knyazev S.Yu., Farzalieva G.Sh., Tuf I.H. 2017b. A contribution to the myriapod fauna of the Omsk Area, Siberia, Russia (Myriapoda: Diplopoda, Chilopoda)// Arthropoda Selecta. Vol.26. No.2.P.113118.

Nefediev P.S., Tuf I.H., Farzalieva G.Sh. 2017c. Centipedes from urban areas in southwestern Siberia, Russia (Chilopoda). Part 2. Geophilomorpha // Arthropoda Selecta. Vol.26. No.1. P.8-14.

Nefedieva J.S., Nefediev P.S. 2008. Ecofaunistical investigations of millipedes (Diplopoda) in the environs of Lake Teletskoe // Myriapoda and Onychophora of the World Diversity, Biology and Importance. Abstracts of 14th International Congress of Myriapodology. Staatliches Museum für Naturkunde, Görlitz. Peckiana. Vol.6. P.123-124.

Poloczek A., Pfeiffer M., Schneider R., Müchlenberg M. 2016. The Chilopoda (Myriapoda) of the KhenteyMountain Range, Northern Mongolia. Communities of different forest-types under a varying fire regime / / European Journal of Soil Biology. Vol.74. P.114 120.

Poloczek A., Pfeiffer M., Schneider R., Muehlenberg M., Nefediev P. 2017. The myriapods (Chilopoda and Diplopoda) of the Khentey-Mountain Range. Communities from different forest-types under a varying fire regime // B. Bayartogtokh, Ch. Dulamsuren (eds). Abstracts of the International Conference on "Biodiversity research of Mongolia”, Ulaanbaatar, Mongolia. Ulaanbaatar: National University of Mongolia Press. P.35-36.

Rybalov L.B. 2002. [Zonal and landscape changes in soil invertebrate populations in a near-Yenisei River region of middle Siberia and the role of temperature adaptations in the meridional (zonal) distribution of invertebrates] // Russian Entomological Journal. Vol.11. No.1. P.77-86 [in Russian, with English summary].

Rybalov L.B., Vorobiova I.G. 2002. [Population of soil invertebrates in taiga ecosystems of the middle flow of the Yenisei River] // Izuchenie, sokhranenie i vosstanovlenie bioraznoobraziya ekosistem na yeniseiskom ekologicheskom transekte: Zhivotnyi mir, etno-ekologicheskie issledovaniya. Vol.2. Moscow: IEE RAS Publ. P.8-42 [in Russian].

Semenov Yu.M., Lysanova G.I. 2016. [The landscape map of Khakassia] // Izvestiya Irkutskogo gosudarstvennogo universiteta, Seriya Nauki o Zemle. Vol.18. P.128-139 [in Russian with English summary].
Sergeeva E.V. 2010. [Species diversity of centipedes (Chilopoda) in the southern taiga subzone of Western Siberia] // Tobolsk Nauchnyi - 2010. Materialy Vserrossiyskoi nauchno-prakticheskoi konferentsii. Tobolsk. P.37-39 [in Russian].

Shear W.A. 1990. On the Central and East Asian milliped family Diplomaragnidae (Diplopoda, Chordeumatida, Diplomaragnoidea) // American Museum Novitates. No.2977. P.1-40.

Stuxberg A. 1876a. Myriopoder från Sibirien och Waigatsch ön samlade under Nordenskiöldska expeditionen 1875 // Öfversigt af Kongliga Vetenskaps-Akademiens Förhandlingar. Årg.33. No.2. S.11-38.

Stuxberg A. 1876b. On the Myriopoda, from Siberia and Waigatsch Island, collected during the expedition of Prof. Nordenskiöld, 1875 // Annals and Magazine of Natural History. Ser.4. Vol.17. P.306-318.

Tuf I.H. 2007. [Diversity of selected taxa of invertebrates of the Altai (East Kazakhstan)] // Sovremennye podkhody k zaschite biologicheskoi variativnosti v kontekste dostizheniya ustoichivogo razvitiya Respubliki Kazakhstan. Sbornik Mezhdunarodnogo Kazakhstansko-Cheshskogo nauchnogo seminara, Ust-Kamenogorsk. Ust-Kamenogorsk: East Kazakhstan State University Publ. P.56-64 [in Czech, with English summary].

Tuf I.H., Dányi L., Kuda F., Chlachula J. 2010. Centipedes of Kazakhstan - new records from Altai // High Mountain Soils Biodiversity, Tbilisi. Tbilisi: Ilia State University Publ. P.11-12.

Volkova Yu.S. 2016. An annotated catalogue of geophilomorph centipedes (Chilopoda, Geophilomorpha) from the European part of Russia // Zoologicheskii Zhurnal. Vol.95. No.6. P.669-678 [in Russian with English summary].

Vorobiova I.G. 1999. [Ecological and faunistic characteristics of myriapod populations in the mid-flow region of the Yenisei River]// Problemy pochvennoi zoologii. Materialy II (XII) Vserossiiskogo soveschaniya po pochvennoi zoologii. Moscow: KMK Sci. Press. P.3334 [in Russian].

Vorobiova I.G., Rybalov L.B., Rossolimo T.E., Zalesskaja N.T. 2002. [Zonal and landscape distribution of the myriapod fauna and populations (Myriapoda) in the Yenisei River basin] // Izuchenie, sokhranenie i vosstanovlenie bioraznoobraziya ekosistem na Yeniseiskom ekologicheskom transekte: Zhivotnyi mir, etno-ekologicheskie issledovniya. Vol.2. Moscow: IEE RAS Publ. P.60-71 [in Russian].

Zalesskaja N.T. 1978. [Identification book of the lithobiomorph centipedes of the USSR]. Moscow: Nauka Publ. 212 p. [In Russian]

Zalesskaja N.T., Titova L.P., Golovatch S.I. 1982. [The myriapod fauna of the Moscow Region] // M.S. Ghilarov (ed.). Pochvennye bespozvonochnye Moskovskoi oblasti. Moscow: Nauka Publ. P.179-200 [in Russian].

Responsible editor K.G. Mikhailov 